\title{
Invasive grass negatively affects growth and survival of an imperiled butterfly
}

\author{
Cale S. Nordmeyer ${ }^{1,2, *}$, Erik Runquist ${ }^{1}{ }_{\text {, Seth Stapleton }}{ }^{1,2}$ \\ ${ }^{1}$ Conservation Department, Minnesota Zoo, Apple Valley, MN 55124, USA \\ ${ }^{2}$ Department of Fisheries, Wildlife and Conservation Biology, University of Minnesota, St. Paul, MN 55108, USA
}

\begin{abstract}
With only $~ 1 \%$ of native prairie remaining in North America, populations of many prairie-obligate species, including the imperiled Dakota skipper butterfly, have drastically declined in recent decades. Unfortunately, population recovery is impeded by an insufficient understanding of Dakota skipper biology. Because larvae have never been naturally observed in the wild, even basic life history elements including preferred host plant(s) are not well understood, and potential hosts have been inferred from grasses inhabiting remnant sites rather than direct observations. To improve our understanding of Dakota skipper biology and habitat needs and inform recovery efforts, we conducted a no-choice performance experiment offering larvae 1 of 5 commonly occurring native grasses and 2 pervasive invasive grass species found across their historic range. We monitored larvae during key life history intervals and evaluated host plant quality by measuring larval and pupal mass, time to pupation, and survivorship. Larvae fed on all offered host grasses, but mass, phenology, and survivorship varied among treatments. Larvae reared on prairie dropseed and porcupine grass had the highest survival, the shortest time to adulthood, and the greatest mass, whereas larvae provided smooth brome and Kentucky bluegrass fared poorly for all observed metrics. All other grasses offered during the study were deemed 'medium' quality. Our results suggest that although larvae can feed on a variety of potential host plants, these hosts vary in quality. Invasive grasses across prairies in North America may pose an ecological trap to the conservation of Dakota skipper and other prairie-obligate Lepidoptera.
\end{abstract}

KEY WORDS: Ecological trap $\cdot$ Hesperia dacotae $\cdot$ Host quality $\cdot$ Invasive species $\cdot$ Larval development $\cdot$ Lepidoptera $\cdot$ Prairie $\cdot$ Skipper

\section{INTRODUCTION}

Grasslands are among the most imperiled ecosystems in North America (White et al. 2000), with less than $1 \%$ of native tallgrass prairies remaining (Samson \& Knopf 1994). The widespread loss of grasslands over the last century has largely resulted from agricultural conversion and other development (White et al. 2000), markedly reducing habitat available to prairie-dependent species and yielding an increasingly fragmented landscape which promotes colonization by non-native plant species (Cully et al. 2003).

${ }^{*}$ Corresponding author: cale.nordmeyer@state.mn.us
This reduction and degradation of habitat has resulted in the decline of many prairie-obligate species (Leach \& Givnish 1996, Brennan \& Kuvlesky 2005, Miles \& Knops 2009).

The Dakota skipper Hesperia dacotae (Skinner, 1911) is a habitat specialist of northern tallgrass and upland dry mixed prairies (Royer \& Marrone 1992) that has been severely impacted by habitat loss. Once predictably common from southeastern Saskatchewan and southern Manitoba through North Dakota, South Dakota, Minnesota, Iowa, and northern Illinois (McCabe 1981, Dana 1991, Cochrane \&

() The authors 2021. Open Access under Creative Commons by Attribution Licence. Use, distribution and reproduction are unrestricted. Authors and original publication must be credited. 
Delphey 2002), Dakota skipper populations have declined precipitously in recent decades. The species is now extirpated from more than $76 \%$ of its known historic localities and is listed at national COSEWIC 2014, USFWS 2014 and international levels (Royer 2019). Even in protected remnant grassland parcels, populations of some prairie endemic butterflies continue to decline (Schlicht et al. 2009, Swengel \& Swengel 2015). Habitat degradation may now pose a more significant threat to the long-term viability of Dakota skipper populations than complete habitat destruction, although the mechanism(s) underlying the declines remain(s) unclear (e.g. displacement of necessary nectar sources, preferred larval hosts, or something else entirely) (USFWS 2011, 2018). Indeed, non-native plants may pose additional novel threats to imperiled Lepidoptera by creating population sinks and even ecological traps if use of those novel plants as oviposition sites and/or larval hosts is maladaptive (Schlaepfer et al. 2005, Keeler \& Chew 2008, Yoon \& Read 2016).

Dakota skipper life history under in situ conditions is poorly understood (Dana 1991, Cochrane \& Delphey 2002, USFWS 2014). As with other grass skippers, Dakota skipper larvae feed exclusively on graminoids like grasses and sedges. Larvae have never been observed in the wild, however, so it is unclear if Dakota skipper larvae are specialists (e.g. feeding on species in a single genus, or even a single species) or polyphagous (perhaps due to variability in availability). Host plants are assumed for many grass skippers based on oviposition observations, adult proximity, or unsubstantiated reports from field guides or other anecdotal sources (MacNeill 1964, Narem \& Meyer 2017). To date, research has focused on developing environmental and vegetative associations of Dakota skippers in remnant populations (Royer et al. 2008, Rigney 2013, Seidle 2018), but these efforts have not been paired with observed interactions. A better understanding of how Dakota skippers use prairie vegetation at a fine spatial scale (e.g. host foraging and shelter construction) is needed to inform conservation actions, including in situ habitat management (Rigney 2013) and ex situ breeding and reintroduction programs (Delphey et al. 2016, USFWS 2019). Indeed, despite the increasing use of ex situ breeding and reintroduction programs as conservation tools for imperiled butterflies (Crone et al. 2007, Thomas et al. 2011), their successes historically have been limited and difficult to quantify (Oates \& Warren 1990); many likely are unsuccessful due to poor speciesspecific knowledge (Schultz et al. 2008, Bierzychudek
\& Warner 2015) and/or scientific rigor (Daniels et al. 2018).

One of the most basic information needs for the conservation of an herbivorous insect is an understanding of the relationships between the target species and their prospective host plants, particularly as novel potential host plants are invading suitable habitat. We designed and implemented a no-choice performance experiment to better understand the relationship between larval host plants and Dakota skipper ecology and fitness. We leveraged the existing Dakota skipper ex situ conservation program at the Minnesota Zoo (Apple Valley, Minnesota, USA) and measured key life history parameters of larvae reared on different potential host grasses. This study improves our understanding of Dakota skipper host plant associations and promotes their conservation by informing in situ prairie management and enabling ex situ programs to optimize husbandry protocols.

\section{MATERIALS AND METHODS}

\subsection{Study design}

We implemented a no-choice performance study design in which Dakota skipper larvae were offered a single host plant species during their entire larval period. Dakota skippers are univoltine, with just a single generation annually. We conducted the experiment with the 2016-2017 and the 2017-2018 Dakota skipper generations (Gen 1 and Gen 2, respectively) reared at the Minnesota Zoo. For each cohort, we randomly assigned larvae annually to 1 of 7 treatment grass species, including 5 native species: big bluestem Andropogon gerardii, side-oats gramma Bouteloua curtipendula, porcupine grass Hesperostipa spartea, little bluestem Schizachyrium scoparium, and prairie dropseed Sporobolus heterolepis; and 2 invasive species: smooth brome Bromus inermis and Kentucky bluegrass Poa pratensis (Table 1). We initially intended to incorporate Junegrass Koeleria cristata as an eighth host plant, but it was ultimately removed from the study due to poor survivorship of available plants. These grass species were chosen as they are major dry-mesic prairie grasses co-occurring with Dakota skippers and had either been used in a previous no-choice performance experiment conducted by Dana (1991; Table 2), or were speculated to be used by Dakota skippers in situ.

We assessed survival at multiple life history stages and transitions and collected biometric data includ- 
Table 1. The different host plant treatment species offered to Dakota skipper larvae at the Minnesota Zoo during 2016 to 2018. For analyses, host plants were grouped as native or non-native and as cool season $\left(\mathrm{C}_{3}\right)$ or warm season $\left(\mathrm{C}_{4}\right)$. The experiment was conducted for 2 generations (Gen 1 and Gen 2) with differing numbers of larvae being randomly assigned to each host treatment

\begin{tabular}{|lcccc|}
\hline Host species & Origin & Seasonality & $\mathrm{n}$ (Gen 1) & $\mathrm{n}$ (Gen 2) \\
\hline $\begin{array}{l}\text { Big bluestem } \\
\text { Andropogon gerardii }\end{array}$ & Native & $\mathrm{C}_{4}$ & 27 & 29 \\
$\begin{array}{l}\text { Side-oats grama } \\
\text { Bouteloua curtipendula }\end{array}$ & Native & $\mathrm{C}_{4}$ & 27 & 33 \\
$\begin{array}{l}\text { Porcupine grass } \\
\text { Hesperostipa spartea }\end{array}$ & Native & $\mathrm{C}_{3}$ & 26 & 29 \\
$\begin{array}{l}\text { Little bluestem } \\
\text { Schizachyrium scoparium }\end{array}$ & Native & $\mathrm{C}_{4}$ & 27 & 28 \\
$\begin{array}{l}\text { Prairie dropseed } \\
\text { Sporobolus heterolepis }\end{array}$ & Native & $\mathrm{C}_{4}$ & 25 & 31 \\
$\begin{array}{l}\text { Smooth brome } \\
\text { Bromus inermis }\end{array}$ & Non-native & $\mathrm{C}_{3}$ & 27 & 27 \\
$\begin{array}{l}\text { Kentucky bluegrass } \\
\text { Poa pratensis }\end{array}$ & Non-native & $\mathrm{C}_{3}$ & 27 & 35 \\
\hline
\end{tabular}

Table 2. Graminoid species offered to Dakota skipper larvae at the Minnesota Zoo ex situ. All of the graminoid species have solicited a feeding response from neonate larvae. Nonnative species that have been introduced to North America are indicated in bold

\begin{tabular}{|c|c|}
\hline Scientific name & Common name \\
\hline Andropogon gerardii ${ }^{\mathrm{a}, \mathrm{c}}$ & Big bluestem \\
\hline Bouteloua curtipendula ${ }^{\mathrm{a}, \mathrm{b}}$ & Side-oats grama \\
\hline Bouteloua dactyloides & Buffalo grass \\
\hline Bouteloua gracilis & Blue grama \\
\hline Bromus inermis $^{\mathrm{a}}$ & Smooth brome \\
\hline Bromus kalmia & Prairie brome \\
\hline Elymus canadensis & Canada wild-rye \\
\hline Hesperostipa comate & Needle-and-thread grass \\
\hline Hesperostipa spartea ${ }^{\mathrm{a}, \mathrm{b}, \mathrm{c}}$ & Porcupine grass \\
\hline Koeleria macrantha ${ }^{\mathrm{b}, \mathrm{c}}$ & Junegrass \\
\hline Muhlenbergia racemosa & Marsh muhly \\
\hline Muhlenbergia richardsonis & Mat muhly \\
\hline Nassella viridula & Green needlegrass \\
\hline Panicum virgatum & Switchgrass \\
\hline Phleum pretense $^{c}$ & Timothy grass \\
\hline Poa pratensis $^{\mathrm{a}, \mathrm{b} . \mathrm{c}}$ & Kentucky bluegrass \\
\hline Schizachyrium scoparium ${ }^{\text {a.b }}$ & Little bluestem \\
\hline Sorghastrum nutans & Indian grass \\
\hline Sporobolus cryptandrus & Sand dropseed \\
\hline Sporobolus heterolepis ${ }^{\mathrm{a} . \mathrm{b}}$ & Prairie dropseed \\
\hline Carex brevior & Plains oval sedge \\
\hline Carex pensylvanica & Pennsylvania sedge \\
\hline \multicolumn{2}{|c|}{$\begin{array}{l}{ }^{a} \text { Species incorporated into this study; }{ }^{\text {b }} \text { Species offered to } \\
\text { neonate Dakota skippers as part of a similar no-choice } \\
\text { performance experiment by Dana }(1991) ;{ }^{\text {cSpecies of- }} \text { - } \\
\text { fered to neonate Dakota skippers as part of a similar no- } \\
\text { choice performance experiment by McCabe (1981) }\end{array}$} \\
\hline
\end{tabular}

ing wet mass (ten-thousandth of a gram) at the time of winter diapause (late October to early November), pupa mass (mid- to late June; ten-thousandth of a gram) and cumulative degreedays (DD) from post-winter diapause to pupation.

\subsection{Larval husbandry}

Larvae were reared following protocols developed by the Minnesota Zoo. Within a few hours of hatching, we placed neonates individually in a $50 \mathrm{ml}$, transparent plastic tube with living leaf blades of the randomly assigned host grass fed through a foam stopper in the top. Grasses and vials with larvae were kept indoors in a temperaturecontrolled laboratory, at a constant $25^{\circ} \mathrm{C}$ under full spectrum, T5 fluorescent grow lights, and timers were set to mimic natural day-night cycles in Apple Valley, Minnesota $\left(44.765^{\circ} \mathrm{N}, 93.201^{\circ} \mathrm{W}\right)$ in mid-July. All larvae showed signs of feeding (e.g. notches in the leaves, frass accumulation) within $72 \mathrm{~h}$ of placement.

After 1 to $2 \mathrm{wk}$, at the second instar developmental stage (i.e. early August), we transitioned larvae to a host grass planted in Vigoro ${ }^{\circledR}$ All-Purpose Garden Soil, in 4 inch diameter, 4 inch tall, round plastic pots. All plants were in their second growing season and approximately 20 to $25 \mathrm{~cm}$ tall; culms comprised approximately $25 \%$ of the growing surface. We used plants that had enough biomass to potentially sustain a Dakota skipper throughout its entire larval development, but were not so massive as to not fit in a 4 inch pot. We sealed the pots with an upright, finemesh screen cage to prevent the escape of larvae and invasion by larval predators while providing the larvae full access to the host plant (Fig. 1). We selected this life stage to transition larvae to full plants to accommodate an apparent shift in feeding strategies for Dakota skipper larvae, from chewing notches mid-way on the grass leaf, to shelter building at the base of host grass (Minnesota Zoo unpubl. data). Because the amount of dead material and duff was inconsistent among plants, all dead material was removed from each plant prior to placing the larvae. We added segments of dried leaf blades of each respective assigned host, $5 \mathrm{~cm}$ in length and weighing a total of $2 \mathrm{~g}$, to each pot to standardize the amount of material available for shelter construction. 

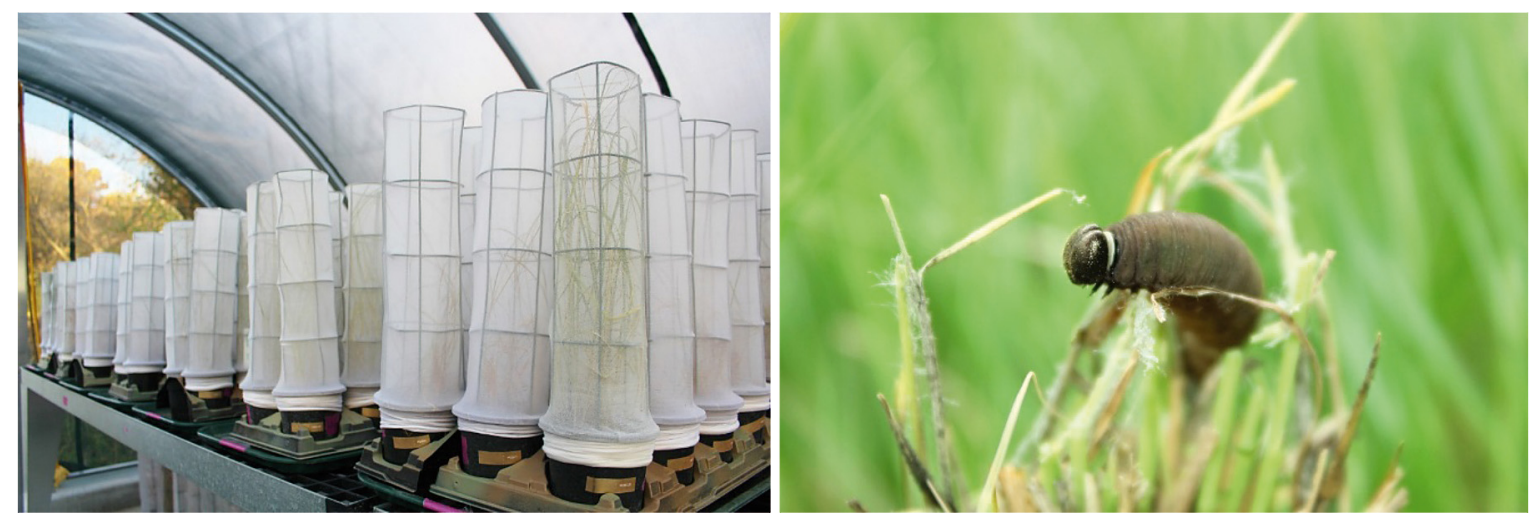

Fig. 1. (Left) Experimental husbandry setup used to rear Dakota skippers. Setups consisted of a 4 inch plastic pot containing 1 of 7 different host grass species, and covered with nylon mesh. Larvae were reared in an outdoor, open-air, hoop-house at the Minnesota Zoo before and after winter diapause. (Right) Fifth instar Dakota skipper larva peering out of a shelter made from woven prairie dropseed leaves

Larvae and their associated potted plants were then housed in an outdoor, screened hoop-house at the Minnesota Zoo.

Host plants were bottom-watered and exteriors were inspected daily for mesh damage, host plant health and potential predators. If a host grass died or was nearly entirely consumed, the larva was removed and placed on a new host plant of the same species. Because Dakota skipper larvae spend most of the time concealed in their shelters and minor disturbance can lead to shelter abandonment (Minnesota Zoo unpubl. data), we only censused them during key life stage transitions (i.e. when all individuals could be censused simultaneously), or opportunistically to change a failing host plant.

Entering winter diapause, we located and removed larvae from their shelters and measured head capsule widths and mass. Dakota skippers enter diapause as either third or fourth instar larvae (Dana 1991). In keeping with the Minnesota Zoo Dakota skipper husbandry protocols to maximize larval survivorship, we overwintered larvae in artificial diapause conditions by placing each individual in a $5 \mathrm{ml}$ plastic vial lined with paper towel. Vials were positioned in plastic cups filled one-third with water-saturated HydroStone ${ }^{\circledR}$ gypsum cement (United States Gypsum Company). Cups were then maintained in an environmental growth chamber at $-5^{\circ} \mathrm{C}$ to mimic natural winter hibernation conditions until the following spring. We recorded the mass of all individuals again post-diapause (early May).

We transitioned post-diapause larvae back to their respective host plants in early May and housed them again in the outdoor, screened hoop-house. Larvae were passively observed daily until they pupated. We determined pupation date by the appearance of the water-repellant wax which encases their shelters near the time of pupation (McCabe 1981, Dana 1991). We extracted pupae from their shelters, and weighed and sexed each individual.

Research specimens that survived to pupation were incorporated into the Minnesota Zoo's formal reintroduction program to a site in southwestern Minnesota from which the species had been recently extirpated (Delphey et al. 2017). For this reintroduction program, individuals were brought out to the release site as pupae, kept in a sealed enclosure at the site, and released daily as they eclosed as adults. We monitored eclosion date and status. Adult morphometrics (wing size, shape, and total dry mass) and reproductive output were not recorded in order to minimize handling of adults and maximize health and survival post-release.

\subsection{Analysis}

We evaluated stage-specific and cumulative survival of Dakota skippers using known fates analyses in the program MARK, version 9.0 (White \& Burnham 1999). After initial placement of neonates on host plants, we censused all individuals during 5 sampling occasions: second instar $(\sim 1-2$ wk after hatching), pre-diapause ( $12 \mathrm{wk}$ after the previous sampling occasion), post-winter diapause emergence ( 26 wk), pupation $(\sim 8-10 \mathrm{wk})$, and adult emergence (1.5 wk). During each sampling occasion, we recorded an individual as alive, dead, or unrecovered. We censored unrecovered individuals from survival analyses for that sampling occasion. Although these stages varied in length, they were the most biologically relevant for evaluating survival 
of Dakota skippers and minimized disturbance to larvae.

We created a set of 8 candidate models based on a priori hypotheses to explain variability in larval survivorship (see Table 3). We explored models incorporating the 7 host plant species as well as time-varying survival and time-constant survival. We considered additive and interactive relationships between the host plant species and time steps (e.g. to test the hypothesis that survival varied among host plant treatments differently over time). We also hypothesized that some aspects of host plant biology may affect larval survivorship. We first pooled the host plants into natives (i.e. big bluestem, side-oats grama, porcupine grass, little bluestem, prairie dropseed) and exotics (i.e. smooth brome, Kentucky bluegrass), hypothesizing that native grasses (those grass species Dakota skipper had most recently evolved with) would support higher survivorship than the non-native species. We also pooled host plants into $\mathrm{C}_{3}$ (porcupine grass, smooth brome, Kentucky bluegrass) and $\mathrm{C}_{4}$ (big bluestem, side-oats grama, little bluestem, prairie dropseed) subsets for analyses. It has been hypothesized that $\mathrm{C}_{3}$ (cool-season) grasses are nutritionally superior to $\mathrm{C}_{4}$ (warm-season) grasses (Caswell et al. 1973), and because $\mathrm{C}_{4}$ grasses are often tougher than $\mathrm{C}_{3}$ grasses, they are more difficult for insect herbivores to consume (Caswell \& Reed 1976). To control for potential variation in survival between study years, we incorporated a 'generation' covariate in some models. We assessed support for candidate models using Akaike's information criteria (AIC; Akaike 1974).

We completed all analyses for mass metrics and phenology using R Statistical Software, version 3.5.3 (R Core Team 2019). We evaluated variability in prediapause larval and pupal mass among host plant treatments with ANOVAs and, where appropriate, completed post-hoc Tukey tests. For the analyses in which pupal mass was assessed, we conducted separate analyses by sex because Dakota skipper adults are sexually dimorphic (females are typically about $30 \%$ larger than males; Minnesota Zoo unpubl. data). Preliminary analyses suggested that results were consistent across generations, so we did not incorporate variability by generation in further analyses.

We determined timing of individuals to pupation after winter diapause using a standard degreeday (DD) model (i.e. (maximum daily temperature + minimum daily temperature) $/ 2$ - lower temperature threshold), modified from Dearborn \& Westwood (2014). We used $10^{\circ} \mathrm{C}$ as the lower temperature threshold rather than $6^{\circ} \mathrm{C}$ based on previous Dakota skipper models developed by Gerald Selby for south- ern Minnesota (G. Selby unpubl. data). We used this approach for controlling for phenology to accommodate differences in temperature conditions between the 2 years of the experiment and because larval removal from diapause varied by up to 5 calendar days within each generation. We calculated DD to pupation (rather than adult emergence; cf. Dearborn $\&$ Westwood 2014) because the exact dates of eclosion were not known for some individuals that were included in an ongoing reintroduction project.

We conducted ANOVAs to evaluate variability in accumulated DD from post-diapause to pupation by host plant treatments and used post-hoc Tukey tests where appropriate. Sexes were analyzed separately because Dakota skipper are known to exhibit protandry, in which males eclose before females (Dana 1991), similar to many other butterflies (Fagerström \& Wiklund 1982). For all mass and phenology analyses, we examined Q-Q plots and residuals, and conducted Shapiro-Wilks tests to confirm that assumptions of normality were met.

\section{RESULTS}

We randomly assigned 398 Dakota skipper larvae to 1 of the 7 host plant treatments. A total of 121 individuals survived to pupation, and we documented variability in the target life history metrics: survival, mass of immature stages, and phenology.

\subsection{Survival}

The most highly supported models explaining variation in survival included terms for all host plant species with full time variation (i.e. independent estimates of survival for each host plant species at each time step, or life history stage); the 2 most-supported models included $>99 \%$ of all model weight (Table 3 ). Because the second most-highly supported model only differed from the top model in its inclusion of a term for 'generation', we considered 'generation' an uninformative parameter and based our inference on the most highly supported model (Arnold 2010). Although the host plant $\times$ time model required estimation of many parameters relative to the treatment sample sizes, its support in this modeling framework suggests that there is significant variation in Dakota skipper survival among different host grasses, which is affected by life history stage. Modeling provided no support for more simplistic models (e.g. time varying including an additive relationship with host plant 
Table 3. Model selection results of candidate models explaining variability in survival of Dakota skippers reared on different host plants at the Minnesota Zoo during 2016 to 2018. AIC : corrected Akaike's information criterion

\begin{tabular}{|c|c|c|c|c|c|}
\hline Model description & $\triangle \mathrm{AIC}$ & $\begin{array}{c}\mathrm{AIC}_{\mathrm{c}} \\
\text { weight }\end{array}$ & $\begin{array}{l}\text { Model } \\
\text { likelihood }\end{array}$ & $\begin{array}{l}\text { Number of } \\
\text { parameters }\end{array}$ & Deviance \\
\hline $\begin{array}{l}\text { Survival varies by host plant treatment type, with an interactive } \\
\text { effect with life history stages }\end{array}$ & 0.00 & 0.59 & 1.00 & 35 & 1163.94 \\
\hline $\begin{array}{l}\text { Survival varies by host plant treatment type, with an interactive } \\
\text { effect with life history type and an additive effect of generation }\end{array}$ & 0.71 & 0.41 & 0.70 & 36 & 1162.53 \\
\hline $\begin{array}{l}\text { Survival varies by host plant treatment, with an additive effect } \\
\text { of life history stage }\end{array}$ & 8.72 & 0.01 & 0.01 & 11 & 1222.56 \\
\hline $\begin{array}{l}\text { Survival varies by native and introduced grass types, with an } \\
\text { additive effect of life history stage }\end{array}$ & 20.71 & 0.00 & 0.00 & 10 & 1236.60 \\
\hline $\begin{array}{l}\text { Survival varies by cool- }\left(\mathrm{C}_{3}\right) \text { and warm-season }\left(\mathrm{C}_{4}\right) \text { grass types, } \\
\text { with an additive effect of life history stage }\end{array}$ & 34.49 & 0.00 & 0.00 & 10 & 1250.38 \\
\hline Survival varies by life history stage only & 36.50 & 0.00 & 0.00 & 5 & 1262.52 \\
\hline Survival varies by host plant treatment only & 44.12 & 0.00 & 0.00 & 7 & 1266.09 \\
\hline $\begin{array}{l}\text { Survival constant across life history stages and host plant } \\
\text { treatments }\end{array}$ & 75.46 & 0.00 & 0.00 & 1 & 1309.52 \\
\hline
\end{tabular}

species; time-constant) or models that pooled host plant species by biological characteristics.

Cumulative survival rates derived from the most highly supported model varied significantly among larvae reared on different host plants (Fig. 2), with survival rates exceeding the pooled treatment average for individuals reared on porcupine grass, prairie dropseed, and side-oats grama across nearly all life history stages (Fig. 3). Additionally, stage-specific survival rates varied among host plant species (Fig. 4). All host plant treatments supported relatively high survivorship of larvae (73 to $89 \%$ ) over winter diapause (i.e. the life history stage between pre- and post-diapause). For the pupae to adult eclosion life history interval, survival exceeded $93 \%$ for larvae reared on all treatments other than smooth brome; by contrast, only approximately $43 \%$ of pupae reared on smooth brome successfully eclosed. Although 7 individuals reared on smooth brome survived to pupation, the only 2 males died as pupae, and 3 of the surviving females failed to eclose properly and were unable to fly as adults. Notably, these were the only 3 individuals during the course of the experiment (on any host plant) that survived to adulthood but were unable to expand their wings.

\subsection{Immature stage masses}

Larval mass entering winter diapause varied among host treatments $\left(F_{6,212}=3.620 ; \mathrm{p}=0.0019\right)$. Larvae reared on porcupine grass were significantly larger than those grown on big bluestem, although larval mass did not significantly differ among other treatments (Table 4). Preliminary analyses suggested that

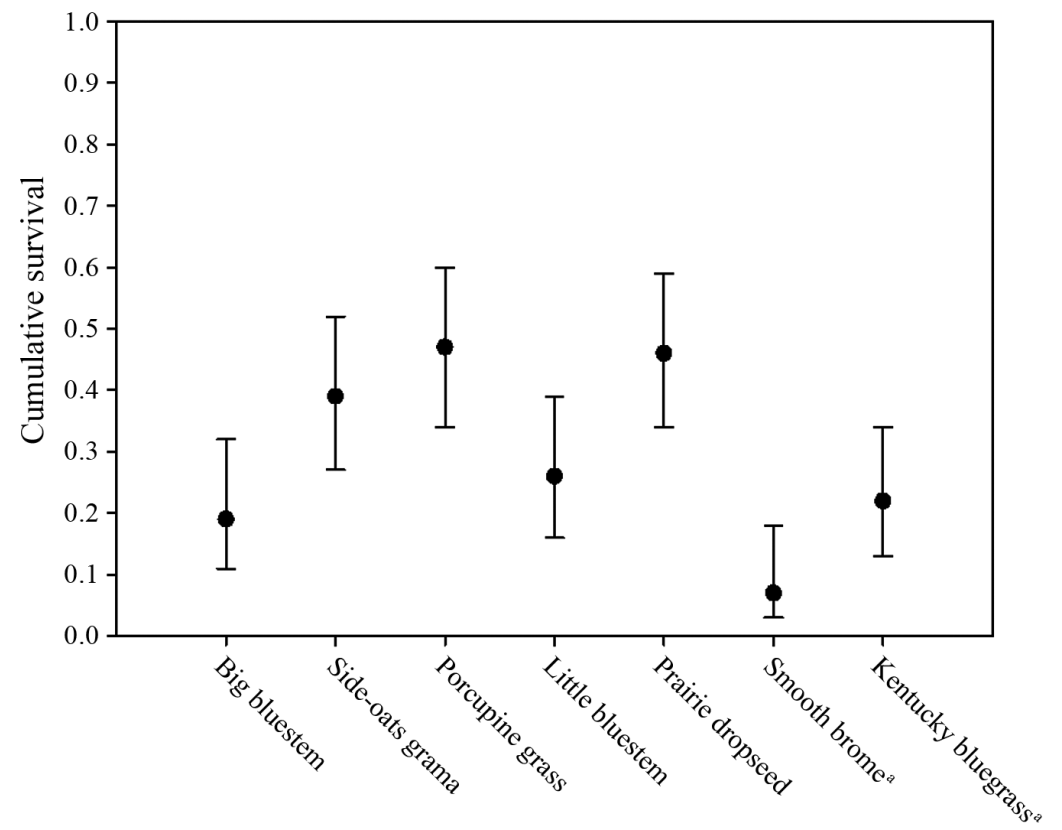

Fig. 2. Cumulative survival estimates for Dakota skippers integrated in an experiment evaluating different host plant species at the Minnesota Zoo during 2016 to 2018 . ${ }^{\text {Invasive grass species }}$ 

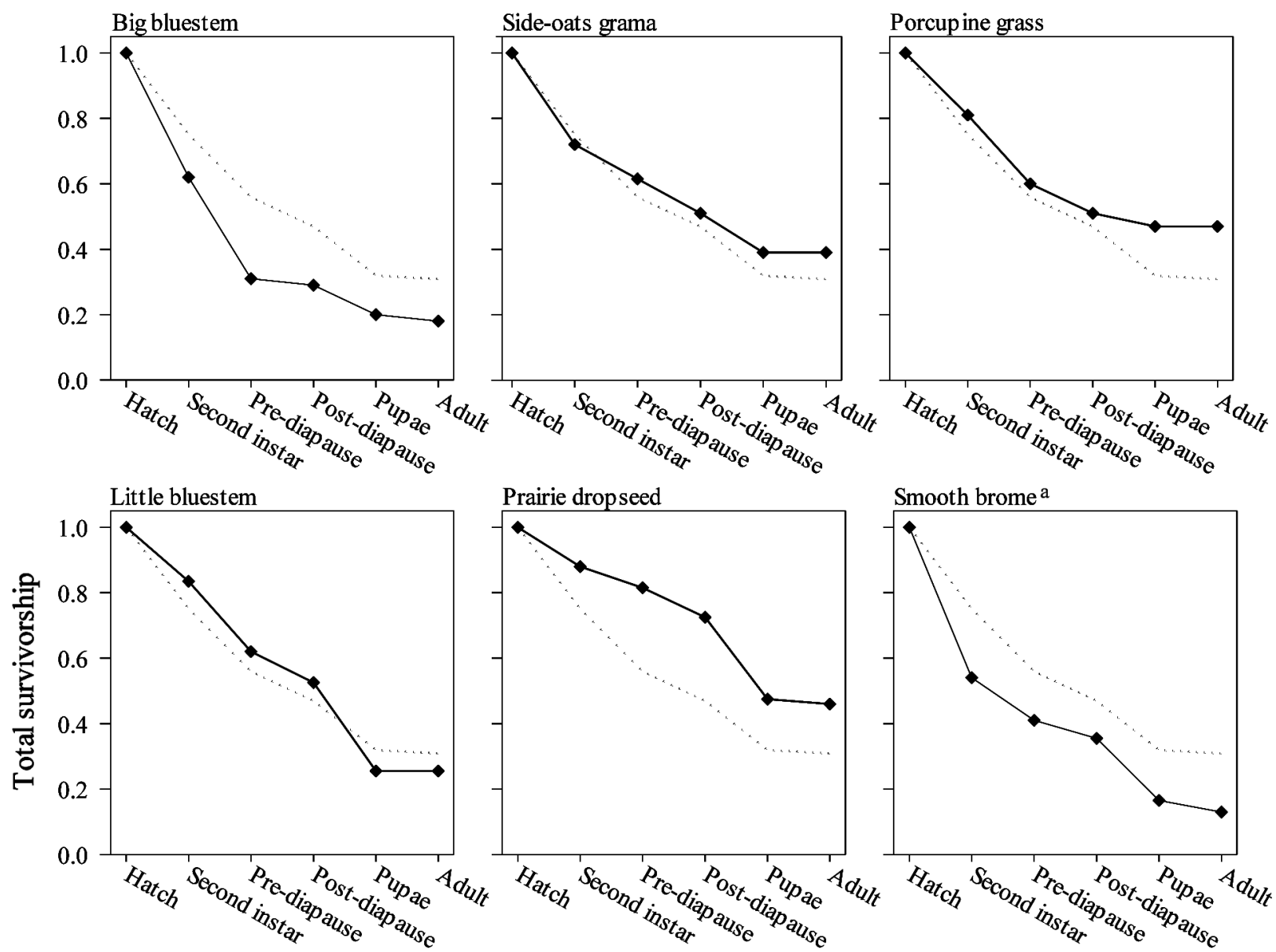

Prairie dropseed
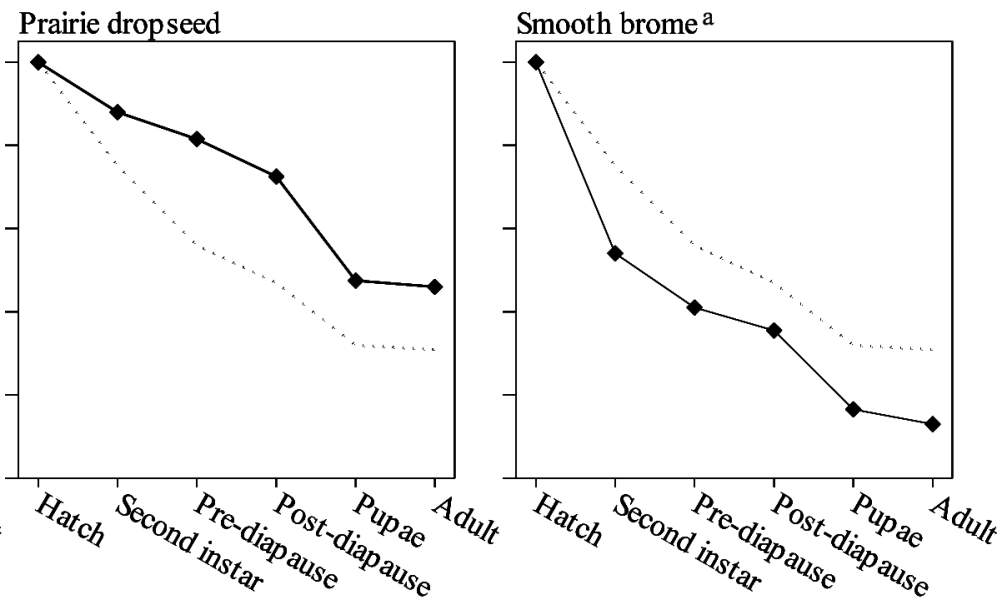

Kentucky bluegrass $^{\mathrm{a}}$

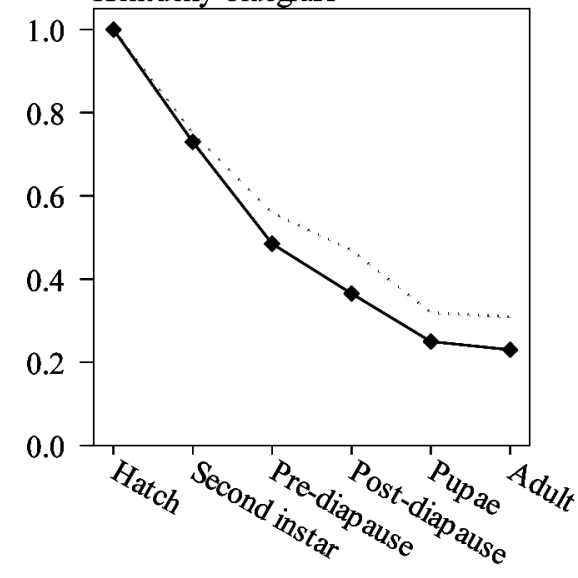

Fig. 3. Total survivorship of Dakota skipper by offered host plant species at defined life-history intervals. (solid line) Cumulative survival at each time step for each host plant treatment; (dotted reference line) mean cumulative survival across all treatments and years; ${ }^{a}$ invasive grass species

although generation (i.e. Gen 1 or Gen 2) did not affect size, pupal mass varied by sex, so we conducted individual ANOVAs by sex to evaluate the relationship between host plant and pupal mass. Females reared on porcupine grass as larvae were significantly larger as pupae than females reared on smooth brome and Kentucky bluegrass (Table 4). Males reared on prairie dropseed were significantly larger than males reared on big bluestem and Kentucky bluegrass (Table 4). Because only 2 males reared on smooth brome survived to pupation, this treatment was excluded from the analysis.

\subsection{Phenology}

DD did not significantly differ between generations $\left(F_{1,123}=0.833 ; \mathrm{p}=0.364\right)$, but did vary by $\operatorname{sex}\left(F_{1,117}=\right.$ 

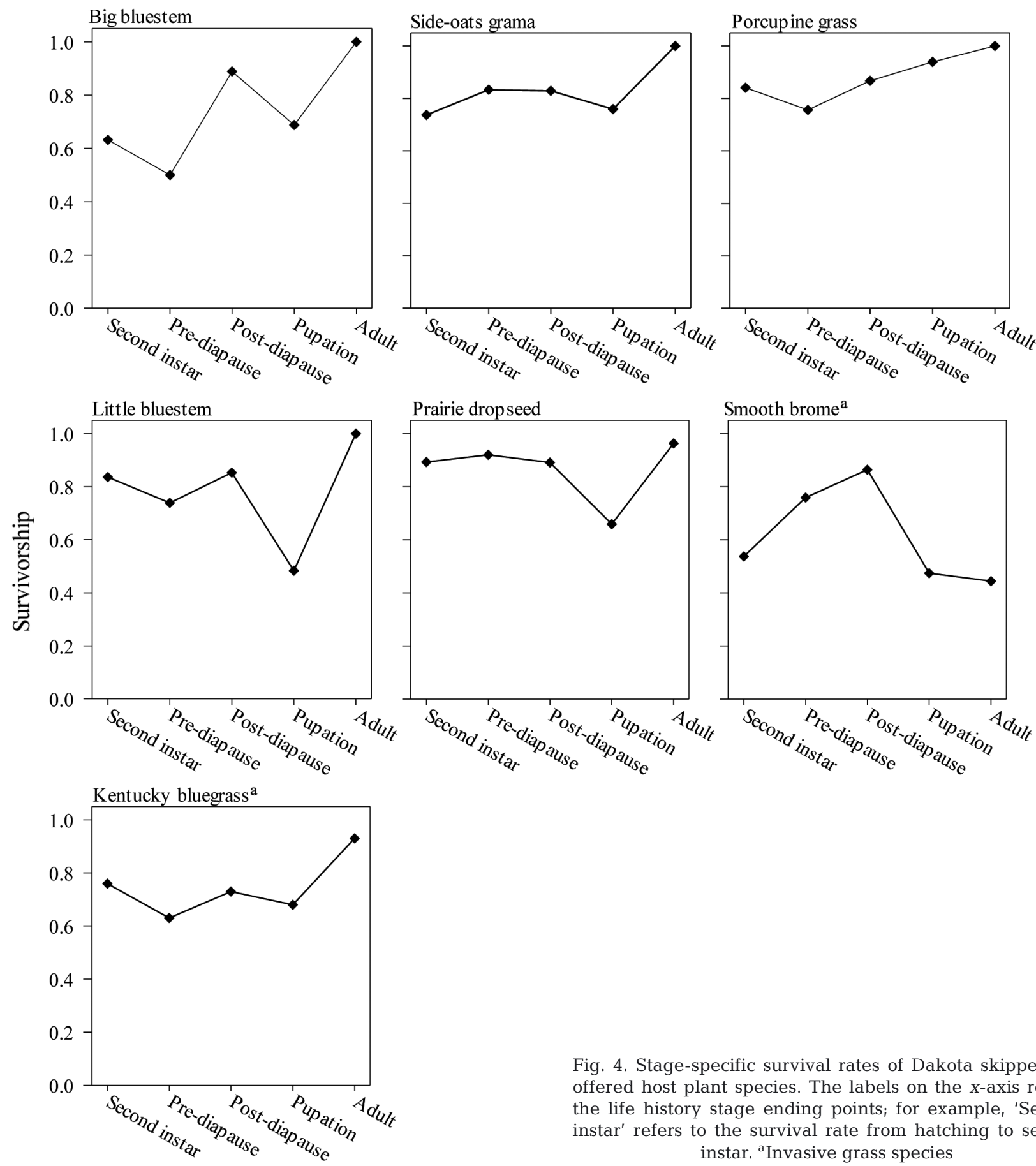

Fig. 4. Stage-specific survival rates of Dakota skippers by offered host plant species. The labels on the $x$-axis reflect the life history stage ending points; for example, 'Second instar' refers to the survival rate from hatching to second instar. ${ }^{a}$ Invasive grass species

31.732 ; $\mathrm{p}<0.001$ ), so male and female DD were analyzed separately. DD accumulation from winter diapause to pupation varied among host plant treatments for female pupae $\left(F_{6,52}=8.561 ; \mathrm{p}<0.001\right)$, with individuals reared on smooth brome taking significantly longer to reach pupation than those reared on little bluestem, side-oats grama, porcupine grass, or prairie dropseed (Fig. 5). Male pupae did not differ by DD to pupation $\left(F_{5,60}=0.771 ; \mathrm{p}=0.599 ;\right.$ Fig. 5$)$, but as noted earlier, males reared on smooth brome were excluded from this analysis due to poor survivorship.

\section{DISCUSSION}

Determining what a caterpillar eats seems like an easily answered question, but in the case of Dakota skipper and many other graminoid-feeding grass- 
Table 4. Dakota skipper mean pre-diapause larval and pupal mass (g) by offered host plant species (95\% confidence intervals). N: individuals surviving to that sampling event. Cells within columns that do not share a letter are significantly different from each other (at $\alpha=0.05$ ) with Tukey's post-hoc test. na: not applicable (as only 2 males reared on smooth brome survived to pupation, this treatment was excluded from the analysis)

\begin{tabular}{|lclclcc|}
\hline & $\mathrm{N}$ & Pre-diapause larvae & $\mathrm{n}$ & Female pupae & $\mathrm{n}$ & Male pupae \\
\hline Big bluestem & 17 & $0.021(0.018-0.024)^{\mathrm{A}}$ & 4 & $0.213(0.182-0.244)^{\mathrm{AB}}$ & 5 & $0.197(0.169-0.225)^{\mathrm{A}}$ \\
Side-oats grama & 38 & $0.026(0.024-0.028)^{\mathrm{AB}}$ & 7 & $0.233(0.214-0.253)^{\mathrm{AB}}$ & 16 & $0.226(0.221-0.242)^{\mathrm{AB}}$ \\
Porcupine grass & 33 & $0.029(0.027-0.031)^{\mathrm{B}}$ & 13 & $0.273(0.252-0.294)^{\mathrm{B}}$ & 12 & $0.230(0.212-0.248)^{\mathrm{AB}}$ \\
Little bluestem $^{\mathrm{B}}$ & 34 & $0.026(0.024-0.028)^{\mathrm{AB}}$ & 6 & $0.219(0.194-0.243)^{\mathrm{AB}}$ & 7 & $0.204(0.180-0.225)^{\mathrm{AB}}$ \\
Prairie dropseed $^{\mathrm{B}}$ & 46 & $0.026(0.025-0.028)^{\mathrm{AB}}$ & 11 & $0.260(0.238-0.283)^{\mathrm{AB}}$ & 15 & $0.245(0.229-0.262)^{\mathrm{B}}$ \\
Smooth brome $^{\mathrm{a}}$ & 19 & $0.024(0.021-0.027)^{\mathrm{AB}}$ & 7 & $0.201(0.170-0.231)^{\mathrm{A}}$ & na & na \\
Kentucky bluegrass $^{\mathrm{a}}$ & 32 & $0.024(0.022-0.027)^{\mathrm{AB}}$ & 7 & $0.204(0.177-0.230)^{\mathrm{A}}$ & 9 & $0.197(0.176-0.182)^{\mathrm{A}}$ \\
Invasive grass species $^{\mathrm{a}}$ & & & & & \\
\hline
\end{tabular}

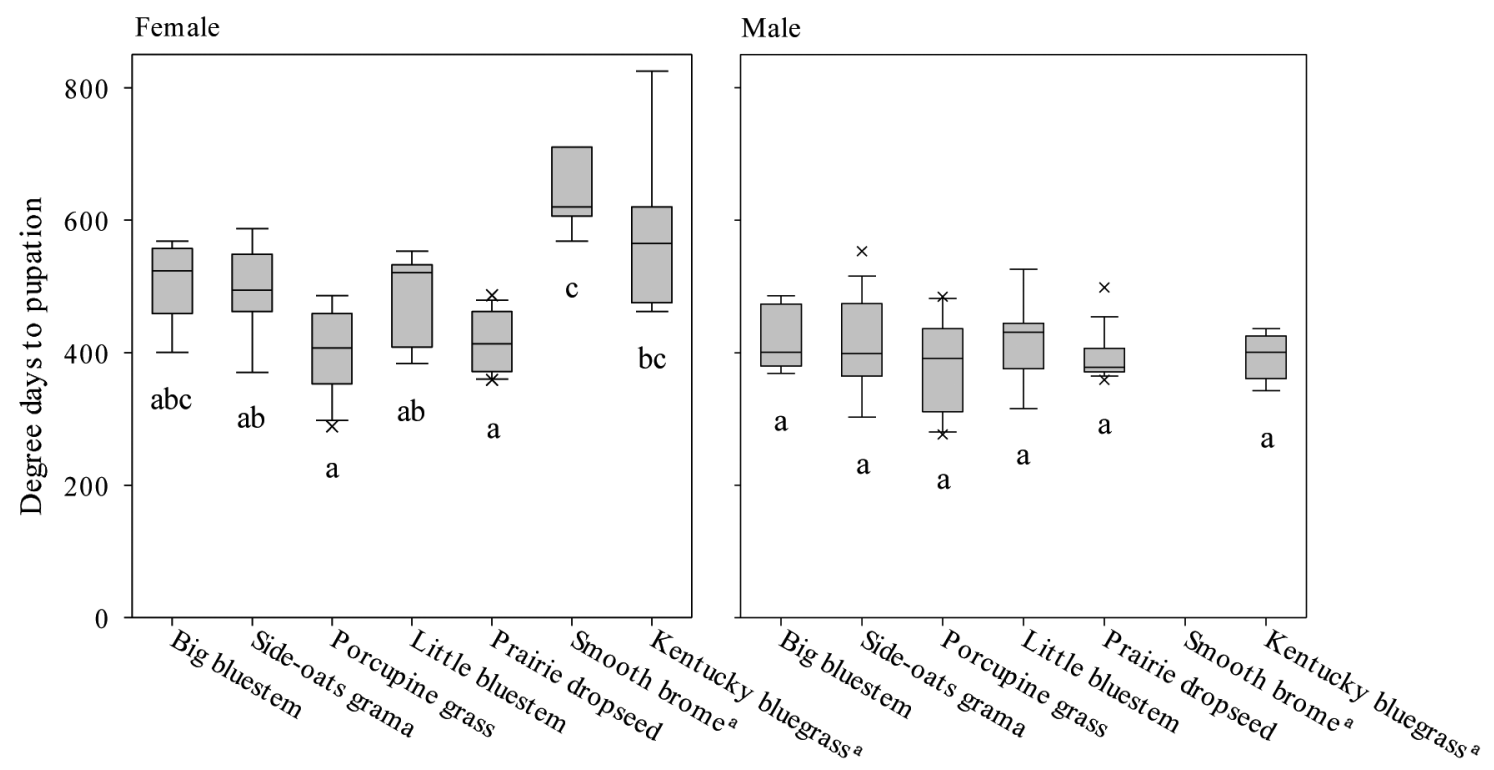

Fig. 5. Accumulated degree-days (DD) to pupation after winter diapause for female (left) and male (right) Dakota skippers. Within each box, black lines denote median values; boxes extend from the 25th to the 75th percentile of each group's distribution of values; whiskers denote adjacent values; x-marks denote outliers. No male Dakota skippers survived to adulthood on smooth brome. Different letters indicate results that are significantly different from each other as analyzed with a post hoc Tukey test. ${ }^{a}$ Invasive grass species

land specialist insects, the answer can be obscure and complex. We documented that Dakota skipper larvae will feed on a wide range of commonly available graminoid hosts that can solely sustain them through all their developmental stages, suggesting they are fairly polyphagous with respect to graminoids. However, variation in pupal mass, timing to pupation, and total survivorship to adulthood highlights that there are differences in host plant quality.

To assess overall host plant quality, we developed a post-hoc scoring system summarizing the parameters evaluated in this study (Table 5). Our system was based on how results from individual metrics likely reflected host plant quality, such that we categorized each metric as 'Low' (1), 'Medium' (2), or 'High' (3) quality. For female pupal mass and timing to pupation, we assigned scores based on the results of posthoc Tukey tests. Host plants that supported statistically larger individuals and individuals that pupated more rapidly were assigned 'High' rankings for pupal mass and timing to pupation, respectively, whereas host plants that yielded statistically smaller individuals and larvae that required longer to reach pupation were assigned 'Low' scores for the respective categories. For cumulative survival, host plant treatments were categorized as 'Low' if larvae reared 
Table 5. Host plant quality rankings. Metrics to assess Dakota skipper performance on different host plants were categorized as 'Low' (score $=1$ ), 'Medium' (2), or 'High' (3). Scores were added to produce a final rank quality of 3 to 9 , with 9 the most optimal host plant

\begin{tabular}{|c|c|c|c|c|}
\hline & $\begin{array}{l}\text { Pupal mass } \\
\text { (female) }\end{array}$ & $\begin{array}{l}\text { Timing to } \\
\text { pupation }\end{array}$ & $\begin{array}{c}\text { Total } \\
\text { survivorship }\end{array}$ & $\begin{array}{c}\text { Rank } \\
\text { quality }\end{array}$ \\
\hline Big bluestem & Medium (2) & Medium (2) & Low (1) & Medium (5) \\
\hline Side-oats grama & Medium (2) & Medium (2) & High (3) & Medium (7) \\
\hline Porcupine grass & High (3) & High (3) & High (3) & High (9) \\
\hline Little bluestem & Medium (2) & Medium (2) & Low (1) & Medium (5) \\
\hline Prairie dropseed & Medium (2) & High (3) & High (3) & High (8) \\
\hline Smooth brome ${ }^{a}$ & Low (1) & Low (1) & Low (1) & Low (3) \\
\hline Kentucky bluegrass ${ }^{a}$ & Low (1) & Low (1) & Low (1) & Low (3) \\
\hline \multicolumn{5}{|l|}{ aInvasive grass species } \\
\hline
\end{tabular}

on that species exhibited survival rates below the pooled treatment mean or 'High' if larvae survived at a rate above the combined mean (Fig. 3). This posthoc assessment identified porcupine grass and prairie dropseed as the most optimal hosts of the provided graminoid species with the highest survival, the largest pupae, and the shortest time to pupation, and these ranked highest in our post-hoc assessment of overall host plant quality. We classified big bluestem, side-oats gramma, and little bluestem as moderate hosts, whereas the 2 invasive species, smooth brome and Kentucky bluegrass, ranked poorly and are considered inferior hosts.

Many herbivorous insects have tight host plant niches that may be brought about by a co-evolutionary arms race with their respective hosts, resulting in specialization on just a few plant species or genera (Ehrlich \& Raven 1964). This is often not the case for graminoid feeding insects, which are characterized as having a broader taxonomic host range (Tscharntke \& Greiler 1995). Although grasses do defend themselves from herbivory (Vicari \& Bazely 1993), this is often achieved less by means of secondary metabolites than through mechanisms such as silicates (Massey et al. 2006), fungal endosymbionts (Ball et al. 2006), and leaf toughness (Nakasuji 1987, Moore \& Johnson 2017). Despite this battery of defense mechanisms, many grass skippers overcome these barriers. Grass skipper larvae hatch with large head-capsules relative to other Lepidoptera, allowing them to feed on some of the toughest grass leaves (Nakasuji 1987, Seko \& Nakasuji 2004). Additionally, fungal endosymbionts, although found to be toxic to many livestock, do not impact the development and survivorship of the tawny-edged skipper Polites themistocles (Jokela et al. 2016), another Hesperiinae grassland specialist butterfly that historically occurs sympatrically with the Dakota skipper.

Larval host plants are often determined by observing oviposition events. For many Lepidoptera, it is often assumed that adults will oviposit on their optimal host plant and that doing so will optimize their fitness (Ehrlich \& Raven 1964, Levins \& MacArthur 1969, Jaenike 1978). However, observations of oviposition alone do not necessarily indicate that the recipient plant is an optimal, or even a palatable, host (Casagrande \& Dacey 2007). Although many herbivorous insects will oviposit on optimal host plants, this trend appears less pronounced in polyphagous species with abundant access to edible species, and additional information is needed to improve our understanding of the response of polyphagous species (Gripenberg et al. 2010). It is often the case that graminoid-feeding Lepidoptera in grassland habitats will oviposit nearly randomly on available substrates, presumably because potential host plants are in close enough proximity for the neonate larvae to find on their own (Wiklund 1984). Dakota skipper oviposition has been rarely observed in the wild (Selby 2006), but includes native bunchgrasses and invasive grasses, as well as other unsuitable live and dead non-graminoid plant material and even inert surfaces (McCabe 1981, Dana 1991, Minnesota Zoo unpubl. data). Similar oviposition 'mistakes' have been recorded in other Hesperia (MacNeill 1964). Thus, female Dakota skipper oviposition behavior may not be mediated by optimal hosts, though more research is needed.

McCabe (1981) first documented that Dakota skipper neonate larvae accepted big bluestem, porcupine grass, Junegrass, Timothy grass Phleum pretense, Kentucky bluegrass, prairie dropseed, and an unspecified Carex species. Twenty-two graminoid species have been offered to neonate Dakota skipper larvae over the course of the ex situ program at the Minnesota Zoo (Table 2), and neonates have fed on all of them within $72 \mathrm{~h}$ of hatching. Although triggering a feeding response by a neonate larva is a good indicator of the plant being a candidate host, it does not necessarily indicate that it is a quality, or sustainable food source (Gómez Jiménez et al. 2014). Thus, it is clear that an understanding of host plant effects throughout development is essential when evaluating the importance of different hosts for a particular insect herbivore and detecting potential sub-lethal effects. 
Our results suggest that Dakota skipper performance does vary among different host plants. We documented variability in all performance metrics for larvae provided different host grass treatments. Dana (1991) reported the high quality of prairie dropseed, but suggested that porcupine grass was likely an unsuitable host given its leaf toughness. Although we did not measure leaf toughness in this experiment, even neonate larvae were capable of feeding on porcupine grass, and our results suggest it is a high-quality host. Importantly, Dana (1991) concluded his studies prior to winter diapause, where larvae had only gone through half their developmental stadia. Our research indicates that performance differences among host plants become amplified in later stages after winter diapause.

\subsection{Future work}

Our controlled, no-choice performance experimental design may not account for variation in host utilization under wild conditions (Forister 2008). As the native prairie habitat of the Dakota skipper is made up of a mosaic of grasses, a next step in understanding their host plant dynamics is to implement a choice study in which larvae have access to multiple species. Although some Lepidoptera larvae may be unable to discern between suitable and unsuitable host plants (Gómez Jiménez et al. 2014), some polyphagous species have demonstrated selection (Nylin et al. 2000, Gamberale-Stille et al. 2014) and are even able to modify their feeding preference in the presence of predators (Bernays \& Graham 1988) or differentially choose alternative hosts if parasitized (Smilanich et al. 2011). We were unable to determine if Dakota skippers can discern between suitable and unsuitable hosts, or if foraging on multiple hosts would promote a fitness advantage (e.g. larger, more fecund adults). Similarly, observations of neonate behavior and mobility (Thompson 1983) in situ or in controlled areas similar to those conducted by Bierzychudek \& Warner (2015) would improve our understanding of Dakota skipper ecology and the threat posed by smooth brome and other invasive species. Unfortunately, traditional experimental host choice studies are less feasible with obligate shelter-building butterflies like Dakota skippers than they can be with other butterflies that will initiate feeding without first building a complex shelter.

Shelter morphometrics and potential variation among grass hosts also require further research. Like many other grass skippers, Dakota skippers defend themselves from predators and the elements in constructed shelters at the base of their host plants (MacNeill 1964). Second instar larvae begin stitching blades of grasses together, and the larvae feed and overwinter in these shelters until finishing development the following spring. The cryptic larvae and their shelters are virtually undetectable in the landscape, and it is unknown how structure construction might vary across host grass species, though variation has been observed within dicot feeding Pyrrhopygini skippers (Greeney et al. 2010a). Due to interspecific variation in leaf size and basal architecture, we expect that larval shelter construction will necessarily vary among host grasses, and that some of these variants may be disadvantageous to Dakota skipper larvae. For example, a more tightly bound shelter may be possible with prairie dropseed (numerous narrow leaf blades around a circular base) relative to little bluestem (fewer broad blades around a flattened base). These differences may result in variations in visibility to predators and parasitoids and microclimatic differences that may influence survivorship and/or growth rates (Greeney et al. 2010b). Anecdotally, over the course of this study, variation in shelter size and orientation above or below surface of the soil line was observed.

\subsection{Management implications}

The invasion of smooth brome into prairies appears to represent a sink that complicates Dakota skipper conservation efforts. Despite the apparent lack of female oviposition preference provided by opportunistic observations, larvae reared exclusively on this exotic grass consistently had the lowest survivorship, smallest pupal mass, and took the longest to reach pupation. Extended development time could indicate that smooth brome does not provide sufficient larval nutritional content (Bauerfeind \& Fischer 2005). Notably, greater pupal mass corresponded with higher overall survivorship and shorter development time (e.g. individuals fed prairie dropseed and porcupine grass), suggesting that longer development time is indicative of a nutritional deficiency or stress.

In addition to lower survivorship and mass, delayed development on suboptimal hosts, like smooth brome, may have serious negative impacts on Dakota skipper populations. Host plant quality can impact the number of annual generations and may have an even greater impact on phenology than temperature in some Lepidoptera (Abarca et al. 2018). 
For a univoltine species with a short reproductive window like the Dakota skipper, delayed development and a shift in adult flight could prevent overlap with potential mates, or asynchrony with preferred adult nectar resources (Van Dyck et al. 2015). Indeed, smooth brome-reared Dakota skippers reached adulthood up to 2 wk later than their siblings reared on other more suitable hosts. Adult Dakota skipper lifespan under natural conditions is likely less than $2 \mathrm{wk}$. Thus, individuals feeding exclusively on smooth brome may not reach adulthood until after the flight and thus be excluded from the year's reproduction.

Egg-laying females seem to exhibit little to no oviposition selection for optimal plant hosts (McCabe 1981, Minnesota Zoo unpubl. data), and as documented here, Dakota skipper neonate larvae will consume host plants that result in poor performance in the long term. As a result, both adults and larval Dakota skippers may be unable to distinguish optimal hosts. The inability to distinguish optimal from suboptimal plants has been observed in other Lepidoptera (Gómez Jiménez et al. 2014). Indeed, female host preference appears to evolve independently from larval host performance (Forister 2005, Friberg et al. 2015). The apparent inability of Dakota skipper to identify prime host plants suggests that the presence of large patches or complete invasions of smooth brome may represent population sinks for Dakota skipper. As smooth brome has already largely invaded much of the Dakota skipper range (DeKeyser et al. 2013), it may be a significant stressor for remnant populations.

Little bluestem has been closely associated with Dakota skipper habitats (Royer \& Marrone 1992, Rigney 2013, Seidle et al. 2018), and big bluestem is the dominant grass species at extant Dakota skipper sites (Rigney 2013). Indeed, native bunch grasses, specifically little bluestem, have been deemed essential for Dakota skipper conservation (USFWS 2018). However, this designation may not be indicative of Dakota skipper biological needs. Results from this experiment suggest that little bluestem and big bluestem are moderate quality host plants (Table 5). Furthermore, it is unlikely that little bluestem alone could support Dakota skipper larvae in situ. For the purposes of this study, all treatment grasses were propagated under laboratory conditions so that they would be of consistent sizes when offered. However, even compared to other $\mathrm{C}_{4}$ grasses, little bluestem develops new growth fairly late into the season (Gillen \& Ewing 1992). Assuming Dakota skipper begin foraging after winter diapause (once average daily temperatures reach about 6 to $10^{\circ} \mathrm{C}_{i}$ Dearborn
\& Westwood 2014), anecdotal observations from field surveys suggest that little bluestem often may not have growth available for forage at this time. Though not characterized to the same extent as little bluestem, porcupine grass and prairie dropseed (Royer \& Marrone 1992) also commonly occur at remnant prairie sites supporting Dakota skipper and are available earlier in the growing season.

Land management practices developed for the support of Dakota skipper should prioritize porcupine grass and prairie dropseed and emphasize the suppression of smooth brome. Given the widespread and sometimes near complete invasions of smooth brome into North American prairies, this may be a tricky prospect and novel approaches may be needed to avoid the potential ecological trap that it may present to Dakota skippers (Schlaepfer et al. 2005). Methodologies utilized to determine Dakota skipper host plant suitability may inform important research for other imperiled graminoid-feeding specialist insects for which much of the life history is unknown (e.g. Poweshiek skipperling Oarisma poweshiek).

Acknowledgements. We thank Dr. Tara Harris, Dr. Ralph Holzenthal, Dr. Kelly Nail and Dr. Karen Oberhauser for their input on an early version of the manuscript. The manuscript was improved by the input from 3 anonymous reviewers. We also extend our gratitude to our past colleagues in the Prairie Butterfly Conservation Program at the Minnesota Zoo: Emily Royer, Clayton Burgraff, Grant Piepkorn, and Megan Trautmiller. This work was funded by the Association of Zoos and Aquariums Conservation Grant Fund and the Disney Conservation Fund (CGF \#15-1290), Minnesota's Environment and Natural Resources Trust Fund (M.L. 2016, Chp. 186, Sec. 2, Subd. 03c1), and Minnesota's Clean Water, Land, and Legacy Amendment Arts and Cultural Heritage Fund. Dakota skipper husbandry activities were conducted under USFWS Native Endangered and Threatened Species Recovery Permit \#TE64079B-2. Minnesota Endangered and Threatened Species Special Permit\# 23229 and USDA/APHIS Permit \#P526-18-01480.

\section{LITERATURE CITED}

Abarca M, Larsen EA, Lill JT, Weiss M, Lind E, Ries L (2018) Inclusion of host quality data improves predictions of herbivore phenology. Entomol Exp Appl 166:648-660

Akaike H (1974) A new look at the statistical model identification. IEEE Trans Automat Contr 19:716-723

Arnold TW (2010) Uninformative parameters and model selection using Akaike's Information Criterion. J Wildl Manag 74:1175-1178

Ball OJP, Coudron TA, Tapper BA, Davies E and others (2006) Importance of host plant species, Neotyphodium endophyte isolate, and alkaloids on feeding by Spodoptera frugiperda (Lepidoptera: Noctuidae) larvae. J Econ Entomol 99:1462-1473

Bauerfeind SS, Fischer K (2005) Effects of food stress and density in different life stages on reproduction in a butterfly. Oikos 111:514-524 
Bernays E, Graham M (1988) On the evolution of host specificity in phytophagous arthropods. Ecology 69:886-892

Bierzychudek P, Warner K (2015) Modeling caterpillar movement to guide habitat enhancement for Speyeria zerene hippolyta, the Oregon silverspot butterfly. J Insect Conserv 19:45-54

Brennan LA, Kuvlesky WP (2005) North American grassland birds: an unfolding conservation crisis? J Wildl Manag 69:1-13

Casagrande RA, Dacey JE (2007) Monarch butterfly oviposition on swallow-worts (Vincetoxicum spp.). Environ Entomol 36:631-636

Caswell H, Reed FC (1976) Plant-herbivore interactions: the indigestibility of $\mathrm{C} 4$ bundle sheath cells by grasshoppers. Oecologia 26:151-156

Caswell H, Reed FC, Stephenson SN, Werner PA (1973) Photosynthetic pathways and selective herbivory: a hypothesis. Am Nat 107:465-480

Cochrane JF, Delphey P (2002) Status assessment and conservation guidelines. Dakota skipper, Hesperia dacotae (Skinner) (Lepidoptera: Hesperiidae), Iowa, Minnesota, North Dakota, South Dakota, and Manitoba. US Fish and Wildlife Service, Twin Cities Field Office, Bloomington, MN

COSEWIC (Committee on the Status of Endangered Wildlife in Canada) (2014) COSEWIC assessment and status report on Dakota skipper (Hesperia dacotae) in Canada. Committee on the Status of Endangered Wildlife in Canada, Ottawa

Crone EE, Pickering D, Schultz CB (2007) Can captive rearing promote recovery of endangered butterflies? An assessment in the face of uncertainty. Biol Conserv 139:103-112

Cully AC, Cully JF, Hiebert RD (2003) Invasion of exotic plant species in tallgrass prairie fragments. Conserv Biol 17:990-998

Dana RP (1991) Conservation management of the prairie skippers Hesperia dacotae and Hesperia ottoe: basic biology and threat of mortality during prescribed burning in spring. Minnesota Agricultural Experiment Station Bulletin 594-1991 (AD-SB5511-S), University of Minnesota, St. Paul, MN

* Daniels JC, Nordmeyer C, Runquist E (2018) Improving standards for at-risk butterfly translocations. Diversity (Basel) 10:67

Dearborn K, Westwood R (2014) Predicting adult emergence of Dakota skipper and Poweshiek skipperling (Lepidoptera: Hesperiidae) in Canada. J Insect Conserv 18: 875-884

DeKeyser ES, Meehan M, Clambey G, Krabbenhoft K (2013) Cool season invasive grasses in Northern Great Plains natural areas. Nat Areas J 33:81-90

Delphey P, Runquist E, Harris T, Nordmeyer C, Smith T, Traylor-Holzer K, Miller PS (eds) (2016) Poweshiek skipperling and Dakota skipper: ex situ feasibility assessment and planning workshop. IUCN/SSC Conservation Breeding Specialist Group, Apple Valley, MN

Delphey P, Nordmeyer C, Runquist E (2017) Plan for the controlled propagation, augmentation and reintroduction of Dakota skipper (Hesperia dacotae). US Fish and Wildlife Service, Bloomington, MN

Ehrlich PR, Raven PH (1964) Butterflies and plants — a study in coevolution. Evolution 18:586-608

Fagerström T, Wiklund C (1982) Why do males emerge before females? Protandry as a mating strategy in male and female butterflies. Oecologia 52:164-166
Forister ML (2005) Independent inheritance of preference and performance in hybrids between host races of Mitoura butterflies (Lepidoptera: Lycaenidae). Evolution 59:1149-1155

Forister ML (2008) Experimental design and the outcome of preference-performance assays, with examples from Mitoura butterflies (Lycaenidae). J Lepid Soc 62:99-105

Friberg M, Posledovich D, Wiklund C (2015) Decoupling of female host plant preference and offspring performance in relative specialist and generalist butterflies. Oecologia 178:1181-1192

*Gamberale-Stille G, Söderlind L, Janz N, Nylin S (2014) Host plant choice in the comma butterfly-larval choosiness may ameliorate effects of indiscriminate oviposition. Insect Sci 21:499-506

Gillen RL, Ewing AL (1992) Leaf development of native bluestem grasses in relation to degree-day accumulation. J Range Manage 45:200-204

Gómez Jiménez MI, Sarmiento CE, Díaz MF, Chautá A, Peraza A, Ramírez A, Poveda K (2014) Oviposition, larval preference, and larval performance in two polyphagous species: does the larva know best? Entomol Exp Appl 153:24-33

Greeney HF, Walla TR, Jahner J, Berger R (2010a) Shelter building behavior of Pyrrhopyge papius (Lepidoptera: Hesperiidae) and the use of the Mayfield method for estimating survivorship of shelter-building Lepidopteran larvae. Zoologia 27:867-872

*Geeney HF, Walla TR, Lynch RL (2010b) Architectural changes in larval leaf shelters of Noctuana haematospila (Lepidoptera: Hesperiidae) between host plant species with different leaf thicknesses. Zoologia 27:65-69

Gripenberg S, Mayhew PJ, Parnell M, Roslin T (2010) A meta-analysis of preference-performance relationships in phytophagous insects. Ecol Lett 13:383-393

Jaenike J (1978) Optimal oviposition behavior in phytophagous insects. Theor Popul Biol 14:350-356

Jokela KJ, Debinski DM, McCulley RL (2016) Effects of tall fescue and its fungal endophyte on the development and survival of tawny-edged skippers (Lepidoptera: Hesperiidae). Environ Entomol 45:142-149

Keeler MS, Chew FS (2008) Escaping an evolutionary trap: preference and performance of a native insect on an exotic invasive host. Oecologia 156:559-568

* Leach MK, Givnish TJ (1996) Ecological determinants of species loss in remnant prairies. Science 273:1555-1558

Levins R, MacArthur RH (1969) An hypothesis to explain the incidence of monophagy. Ecology 50:910-911

MacNeill CD (1964) The skippers of the genus Hesperia in western North America, with special reference to California (Lepidoptera: Hesperiidae). Univ Calif Publ Entomol 35:1-230

*Massey FP, Ennos AR, Hartley SE (2006) Silica in grasses as a defense against insect herbivores: contrasting effects on folivores and a phloem feeder. J Anim Ecol 75:595-603

McCabe TL (1981) Dakota skipper, Hesperia dacotae (Skinner): range and biology, with special reference to North Dakota. J Lepid Soc 35:179-193

*Miles EK, Knops JMH (2009) Grassland compositional change in relation to the identity of the dominant matrixforming species. Plant Ecol Divers 2:265-275

Moore BD, Johnson SN (2017) Get tough, get toxic, or get a bodyguard: identifying candidate traits conferring belowground resistance to herbivores in grasses. Front Plant Sci 7:1925 
Nakasuji F (1987) Egg size of skippers (Lepidoptera: Hesperiidae) in relation to their host specificity and to leaf toughness of host plants. Ecol Res 2:175-183

Narem DM, Meyer MH (2017) Native prairie graminoid host plants of Minnesota and associated Lepidoptera: a literature review. J Lepid Soc 71:225-235

Nylin S, Bergstrom A, Janz N (2000) Butterfly host plant choice in the face of possible confusion. J Insect Behav 13:469-482

Oates MR, Warren MS (1990) A review of butterfly introductions in Britain and Ireland. Report for the Joint Committee for the Conservation of British Insects. World Wildlife Fund for Nature, Godalming

R Core Team (2019) R: a language and environment for statistical computing. R Foundation for Statistical Computing, Vienna. www.r-project.org/

Rigney CL (2013) Habitat characterization and biology of the threatened Dakota skipper (Hesperia dacotae) in Manitoba. MSc thesis, University of Winnipeg

Royer E (2019) Hesperia dacotae. The IUCN Red List of Threatened Species 2019:e.T9968A122963341. doi:10. 2305/IUCN.UK.2019-2.RLTS.T9968A122963341.en (accessed 3 October 2019)

Royer RA, Marrone GM (1992) Conservation status of Dakota skipper (Hesperia dacotae) in North and South Dakota. US Fish and Wildlife Service, Denver, CO

Royer RA, McKenney RA, Newton WE (2008) A characterization of non-biotic environmental features of prairies hosting the Dakota Skipper (Hesperia dacotae, Hesperiidae) across its remaining U.S. range. J Lepid Soc 62:1-17

Samson F, Knopf F (1994) Prairie conservation in North America. Bioscience 44:418-421

Schlaepfer MA, Sherman P, Blossey B, Runge M (2005) Introduced species as evolutionary traps. Ecol Lett 8: 241-246

Schlicht D, Swengel A, Swengel S (2009) Meta-analysis of survey data to assess trends of prairie butterflies in Minnesota, USA during 1979-2005. J Insect Conserv 13: $429-447$

Schultz CB, Russell C, Wynn L (2008) Restoration, reintroduction, and captive propagation for at-risk butterflies: a review of British and American conservation efforts. Isr J Ecol Evol 54:41-61

Seidle KM, Lamb EG, Bedard-Haughn A, DeVink JM (2018) Environmental associations of Hesperia dacotae (Lepidoptera: Hesperiidae) in southeastern Saskatchewan, Canada. Can Entomol 150:652-662

Seko T, Nakasuji F (2004) Effect of egg size variation on survival rate, development and fecundity of offspring in a migrant skipper, Parnara guttata guttata (Lepidoptera: Hesperiidae). Appl Entomol Zool (Jpn) 39:171-176

Selby G (2006) Effects of grazing on the Dakota skipper butterfly; prairie butterfly status surveys 2003-2005. Final

Editorial responsibility: Brendan Godley,

University of Exeter, Cornwall

Reviewed by: 3 anonymous referees report, contract \#A50630. Natural Heritage and Nongame Research Program, Minnesota Department of Natural Resources, St. Paul, MN

Smilanich AM, Mason PA, Sprung L, Chase TR, Singer MS (2011) Complex effects of parasitoids on pharmacophagy and diet choice of a polyphagous caterpillar. Oecologia 165:995-1005

Swengel AB, Swengel SR (2015) Grass-skipper (Hesperiinae) trends in Midwestern USA grasslands during 19882013. J Insect Conserv 19:279-292

Thomas JA, Simcox DJ, Hovestadt RT (2011) Evidence based conservation of butterflies. J Insect Conserv 15: 241-258

Thompson NJ (1983) Selection pressures on phytophagous insects feeding on small plants. Oikos 40:438-444

* Tscharntke T, Greiler HJ (1995) Insect communities, grasses, and grasslands. Annu Rev Entomol 40:535-558

USFWS (US Fish and Wildlife Service) (2011) U.S. Fish and Wildlife Service species assessment and listing priority assignment form-Hesperia dacotae. US Fish and Wildlife Species Profile, Environmental Conservation Online System www.fws.gov/midwest/endangered/insects/ pdf/DAKSKCandidateAssessForm2011.pdf (accessed September 2018)

USFWS (2014) Endangered and threatened wildlife and plants; threatened species status for Dakota skipper and endangered species status for Poweshiek skipperling. US Fish and Wildlife Service, 50 CFR Part 17, Final Rule, p 63672-63748

USFWS (2018) Species status assessment report for the Dakota skipper (Hesperia dacotae). US Fish and Wildlife Service, Bloomington, MN

USFWS (2019) Recovery plan for the Dakota skipper (Hesperia dacotae). Draft. August 2019. US Fish and Wildlife Service, Bloomington, MN

*Van Dyck H, Bonte D, Puls R, Gotthard K, Maes D (2015) The lost generation hypothesis: could climate change drive ectotherms into a developmental trap? Oikos 124: $54-61$

Vicari M, Bazely DR (1993) Do grasses fight back? The case for antiherbivore defenses. Trends Ecol Evol 8:137-141

*White GC, Burnham KP (1999) Program MARK: survival estimation from populations of marked animals. Bird Study 46:S120-S139

White R, Murray S, Rohweder M (2000) Pilot analysis of global ecosystems: grassland ecosystems. World Resources Institute, Washington, DC

*Wiklund C (1984) Egg-laying patterns in butterflies in relation to their phenology and the visual apparency and abundance of their host plants. Oecologia 63:23-29

Y Yoon S, Read Q (2016) Consequences of exotic host use: impacts on Lepidoptera and a test of the ecological trap hypothesis. Oecologia 181:985-996

Submitted: February 12, 2021

Accepted: May 25, 2021

Proofs received from author(s): August 7, 2021 